\title{
Frequency of gram negative bacterial isolates in chronic suppurative otitis media and their sensitivity pattern.
}

\footnotetext{
1. MBBS, M.Phil (Microbiology) Assistant Professor Pathology Sahara Medical College.

2. M.Phil (Microbiology)

Assistant Professor Pathology Sahara Medical College.

3. MBBS, M.Phil Microbiology Demonstrator Pathology Sahara Medical College.
}

Correspondence Address: Dr. Saeeda Nabat ul Hassan Department of Pathology Sahara Medical College. doctor.saeeda@gmail.com

Article received on: 10/11/2020 Accepted for publication: $18 / 01 / 2021$

\begin{abstract}
Saeeda Nabat ul Hassan', Khushbu Farva², Ghulam Asghar Bhutta ${ }^{3}$
ABSTRACT... Objective: To determine frequency of gram negative bacterial isolates and their antibiotic sensitivity pattern among patients with chronic suppurative otitis media. Study Design: Descriptive Cross Sectional study. Setting: Department of Pathology Sahara Medical College Narowal. Period: January 2020 to June 2020. Material \& Methods: Total 126 bacterial isolates were taken from the patients having unilateral or bilateral ear discharge reporting to OPD or emergency department during study period. After taking detailed history, examination and baseline investigations diagnosis was confirmed. Specimens of ear discharge were taken from all patients and sent to the pathology department of study institution to determine culture and sensitivity pattern of Gram-negative bacterial isolates. Consent was taken from ethical review committee. Data was analyzed on SPSS-24. Chi square test was applied on collected data. Results: Bacterial isolates were taken from 126 cases having age 2-54 years with mean age of $11.45 \pm 5.73$ years of either gender. Mostly children less than 8 years of age were found with otitis media. Gram positive bacteria were detected in $41.3 \%$ and gram negative in $55.6 \%$ and candida albicans in $3.2 \%$ out of total 126 bacterial cultures. Out of gram negative cultures, pseudomonas aeruginosa was found in $41.4 \%$, proteus mirabilus in $44.3 \%$ and E.coli in $14.3 \%$ specimens. Conclusion: Gram negative bacteria are common cause of chronic suppurative otitis media in our region, mostly affecting young children. There is variable antibiotic sensitivity pattern depending on cultural, climate changes and previously taken antibiotics.
\end{abstract}

Key words: Bacterial Isolates, Chronic Suppurative Otitis Media, Ear Discharge, GramNegative Bcateria.

Article Citation: Nabat ul Hassan S, Farva K, Bhutta GA. Frequency of gram negative bacterial isolates in chronic suppurative otitis media and their sensitivity pattern. Professional Med J 2021; 28(8):1196-1199. https://doi.org/10.29309/TPMJ/2021.28.08.6205

\section{INTRODUCTION}

Purulent discharge from the ear due to chronic inflammation of middle ear, inner ear, mastoid cavity and Eustachian tube causes by microorganisms is called chronic suppurative otitis media. Eustachian tube is the main route of transmission of infection to the middle ear. ${ }^{1}$ It is a major disease burden on health system in developing and under developed countries. In childhood spontaneous perforation of tympanic membrane occurs due to acute middle ear infection which later on becomes chronic otitis media. It is a most important cause of deafness worldwide. This infection is usually found among children but it can occur in any age. People of rural areas are more prone to this infection and due to unavailability of health care services nearby or due to unawareness most of the patients don't take proper treatment hence infection becomes chronic leading to deafness ultimately. ${ }^{2}$ According to a report of world Health Organization chronic otitis media has prevalence of $5.2 \%$ in East Asia population. It is commonly found in children as Eustachian tube is shorter having more horizontal position than adults. Immune system in children is less developed so cannot resist bacterial infection as efficiently as in adults leading to developing infection. It causes conductive as well as sensory neural hearing loss affecting child development negatively and causing 50,000 deaths worldwide annually. ${ }^{3}$ Factors influencing its prevalence include poor socioeconomic status, passive smoking, nasopharyngeal colonization, illiteracy, poor sanitation and hygiene within and 
outside of homes, cultural factors, overcrowded areas, substandard living conditions and common malnutrition among children in our country. ${ }^{4}$ CSOM is of two types tubotympanic and atticoantral disease. In tubotympanic type perforation is present in pars tensa of tympanic membrane with inflammation of mucosa leading to purulent discharge. When there as only perforation in tympanic membrane without mucosal inflammation and discharge it is called inactive disease. In atticoantral disease retraction pockets develop in pars tensa and flacida containing squamous debris which becomes infected and causes ear discharge. ${ }^{5}$ Commonly isolated organisms from CSOM include Pseudomonas aeruginosa, staphylococcus, E.coli, Proteus mirabilis. Klebsiella Pneumonae, Candida and Aspergilus. In peripheral areas of Pakistan most of the general practitioner treat chronic ear discharge with topical ear drops or peripheral antibiotics so increasing resistance of bacteria, drug safety and toxicity issues. ${ }^{6} \mathrm{CSOM}$ causes mild to moderate deafness in $50 \%$ cases in developing countries which is preventable by early diagnosis and proper treatment by giving antibiotics according to culture and sensitivity of ear discharge specimens. Its morbidity and prevalence can be reduced by increasing awareness in general population. Knowledge and experts of local general practitioners is important to diagnose and treat this disease efficiently which will reduce disability among children due to deafness. ${ }^{7}$

\section{MATERIAL \& METHODS}

It is a cross sectional study conducted at pathology department of Sahara Medical College Narowal after approval from ethical review Committee (2860-ERC-SMCN). Study was started in January 2020 and completed in June 2020 comprising on the duration of six months. Patients presenting to out-patient door of ENT ward or admitted indoor with chronic ear discharge were included in the study using non-probability convenient sampling technique. Sample size was calculated using WHO sample size calculator. Detailed history taken and proper examination of ear done. After establishing diagnosis of chronic suppurative otitis media specimens of ear discharge were taken and sent for culture and sensitivity to the pathology department of the hospital. Disc diffusion method using Mueller-Hinton Agar was applied to determine antibiotic sensitivity. Antibiotics used for testing included Augmentin (30 $\mu \mathrm{g}$ ), Ampicillin (30 mg), Cephradine (30 $\mu \mathrm{g})$, Cephalexin $(30 \mu \mathrm{g})$, Ofloxacin (5 $\mu \mathrm{g})$, Cefotaxime $(30 \mu \mathrm{g})$, Erythromycin $(10 \mu \mathrm{g})$ and Ceftriaxone $(30 \mu \mathrm{g})$. They were placed on agar plates using sterilized forceps. Interpretation of antibiotic susceptibility and resistance was made by measurements of zones according to manufacturer's standard zone size. Percentage sensitive and percentage resistance zone sizes were calculated using formula $P S=c / d \times 100$ and $P R=a / b \times 100$. Al data was documented on a predesigned proforma. Data was analyzed using SPSS-24. Results were presented in the form of tables and graphs. Chi square test was applied on the data.

\section{RESULTS}

Total 126 specimens were sent for culture and sensitivity. Gram negative bacteria were detected in $70(55.6 \%)$, Gram positive in 52(41.3\%) and Candida Albicans in 4(3.2\%) cases. Age range of patients was 2-54 years with mean age of $11.45 \pm 5.73$ years. Frequency of Gram negative bacteria and antibiotic sensitivity pattern was further studied.

\begin{tabular}{|l|c|c|c|}
\hline \multirow{2}{*}{$\begin{array}{c}\text { Age } \\
\text { (years) }\end{array}$} & \multicolumn{3}{|c|}{ Number of Cases } \\
\hline $0-10$ & Male & Female & Total \\
\hline $11-20$ & $8(24.3 \%)$ & $20(28.5 \%)$ & $37(52.8 \%)$ \\
\hline $21-30$ & $5(7.1 \%)$ & $5(7.1 \%)$ & $13(18.6 \%)$ \\
\hline $31-40$ & $3(4.3 \%)$ & $2(4.3 \%)$ & $8(11.4 \%)$ \\
\hline $41-50$ & $4(5.7 \%)$ & $1(1.4 \%)$ & $5(7.1 \%)$ \\
\hline$>50$ & $1(1.4 \%)$ & $1(1.4 \%)$ & $2(2.1 \%)$ \\
\hline Total & $38(54.3 \%)$ & $32(45.7 \%)$ & $70(100 \%)$ \\
\hline
\end{tabular}

There were 38(54.3\%) male and 32(45.7\%) female cases. Most of the cases (52.8\%) were below 10 years of age. In $30(42.8 \%)$ cases only right ear was involved, in 26(37.1\%) left ear was involved and in $14(20 \%)$ cases both ears were involved. 


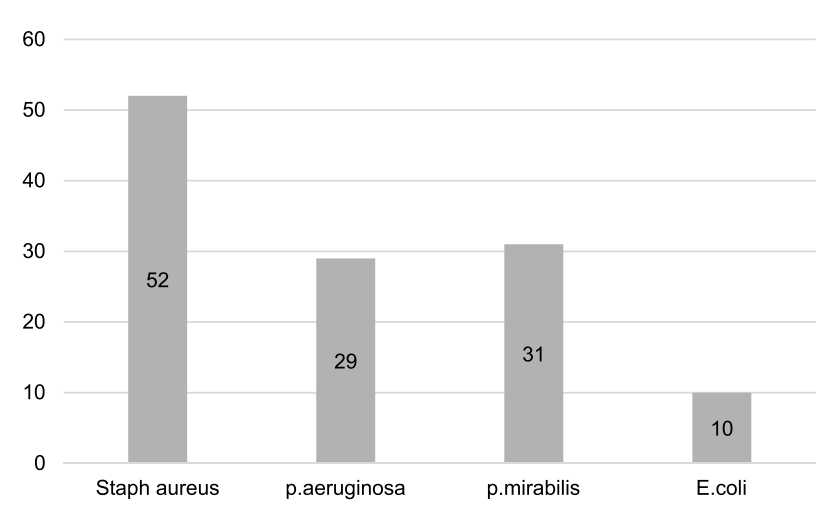

Figure-1. Frequency of microorganisms isolated from bacterial cultures.
Pseudomonas was isolated in 29(41.4\%) specimens and it was sensitive to Augmentin, Ofloxacin and Ampicillin, while showed resistance to Cephalexin and Erythromycin. Proteus Mirabilis was isolated in $31(44.3 \%)$ specimens with sensitivity pattern almost same as pseudomonas aeruginosa. E.coli was isolated in 10(14.3\%), sensitive to Ofloxacin, Amoxiclav, Ampicillin, Erythromycin and Ceftriaxone while resistant to Cephalexin.

\begin{tabular}{|c|c|c|c|c|c|c|c|}
\hline $\begin{array}{l}\text { Bacterial } \\
\text { Species }\end{array}$ & $\begin{array}{c}\text { Total } \\
\text { Isolates }\end{array}$ & Ofloxacin & Amoxiclav & Cephalexin & Ampicillin & Erythromycin & Ceftriaxone \\
\hline $\begin{array}{l}\text { Pseudomonas } \\
\text { aeruginosa }\end{array}$ & $29(41.4 \%)$ & 15 (51.7\%) & $10(34.5 \%)$ & $0(00)$ & $4(13.7 \%)$ & $0(00)$ & $12(41.3 \%)$ \\
\hline Proteus mirabilis & 31 (44.3\%) & $10(32.3 \%)$ & 19 (61.3\%) & $0(00)$ & $7(22.6 \%)$ & $0(00)$ & $22(70.9 \%)$ \\
\hline E.coli & $10(14.3 \%)$ & $9(90 \%)$ & $6(60 \%)$ & $0(00)$ & $6(60 \%)$ & $6(60 \%)$ & $7(70 \%)$ \\
\hline
\end{tabular}

Table-II. Antibiotic sensitivity pattern of Gram negative bacterial isolates $(n=70)$.

\section{DISCUSSION}

This study was conducted on 70 cases with Chronic Suppurative Otitis Media (CSOM) and their specimens of ear discharge were sent for culture and sensitivity. Bacterial cause of CSOM was found in $96.8 \%$ cases including Gram positive bacteria in $41.3 \%$ and Gram negative bacteria in $55.6 \%$ cases, while fungal infection was found in $3.2 \%$ cases. These findings are similar to a study conducted in Multan, a city of Pakistan, reporting Gram positive bacteria in $48 \%$ isolates, Gram negative bacteria in $50 \%$ and fungal source of infection in $2 \%$ isolates. ${ }^{3} \mathrm{~A}$ study conducted in India reported Pseudomonas a most common infective agent in chronic ear discharge found in $49 \%$ isolates, while staphylococcus was found in $26 \%$ and fungi in $2.6 \%$ isolates. They reported $75 \%$ pseudomonas aeruginosa sensitive to Ciprofloxacin (floroquinolone). ${ }^{8}$ In our study $51.7 \%$ pseudomonas cultures were sensitive to Ofloxacin (floroquinolone). Some studies reported Gram positive bacteria as a predominant organism in CSOM followed by Gram negative bacteria. Kalpana et al reported Staphylococcus predominantly in (37.7\%) isolates followed by pseudomonas aeruginosa in $28.1 \%$ isolates. ${ }^{9}$ This difference in results may be due to cultural, geographical and ethnic variations in different countries. ${ }^{10}$ Sharma et al reported pseudomonas the most common isolated microorganism in ear discharge samples accounting $40.38 \%$ bacterial cultures followed by staphylococcus aureus in $34.6 \%$ cultures. They found Tazobactam and piperacillin a most effective drug against pseudomonas species and vancomycin and linezolid were most effective against staphylococcus aureus. ${ }^{11}$ Another study conducted in India reported That most of the cases (46\%) with CSOM were between 2130 years of age while in our study most of the cases $(58 \%)$ were having age $<10$ years which shows that this infection is most prevalent in young children in our community. They reported right ear involvement in 37\% cases, left ear in $54 \%$ and both ears involvement in $9 \%$ cases. ${ }^{12}$ In our study, In $30(42.8 \%)$ cases only right ear was involved, in 26(37.1\%) left ear was involved and in $14(20 \%)$ cases both ears were involved. Gupta et al reported Sensitivity of pseudomonas against Piperacillin and Tazobactam, Imipenem, Amikacin and Amoxiclave. In our study sensitivity of pseudomonas was found against Ofloxacin, 
Ampicillin, Amoxiclav and Ceftriaxone.

\section{CONCLUSION}

In chronic suppurative otitis media microbiological and antibiotic sensitivity pattern of bacterial isolates vary due to variations in community, climate, geographical difference, accessibility of medical care, awareness of disease among health practitioners. It is very important to prescribe antibiotics after knowing culture and sensitivity pattern to avoid drug resistance and to decrease treatment cost and disease burden on the patient. Copyright@ 18 Jan, 2021.

\section{REFERENCES}

1. Neeff M, Biswas K, Hoggard M, Taylor MW, Douglas R. Molecular microbiological profile of chronic suppurative otitis media. Journal of clinical microbiology. 2016 Oct 1; 54(10):2538-46.

2. Shajahan S, Aroor R. Prevalence of Chronic Otitis Media among Undernourished Children. Journal of Health and Allied Sciences NU. 2020 Apr; 10(01):27-30.

3. Naqvi SA, Yaseen R, Naqvi ZA. Otitis media. The Professional Medical Journal. 2019 Feb 10; 26(02):3647.

4. Zahid T, Ahmed Z, Aqeel Z. Microbiology of chronic suppurative otitis media (CSOM) in tertiary care setup, Civil Hospital Karachi, Pakistan. Pak J Surg. 2016; 32(3):176-80.
5. Ahmed K, Ahmed J, Ahmed M, Khan A. Risk assessment by bacteriological evaluation of drinking water of Gilgit-Baltistan. Pak J Zool. 2012; 44(2):427-32

6. Aich ML, Biswas AC, Ahmed M, Joarder MAH, Datta PG, Allauddin M. Prevalence of otitis media with effusion among school going children in Bangladesh. J Otorhinolaryngol. 2009; 15;31-34

7. Shajahan S, Aroor R. Prevalence of Chronic Otitis Media among Undernourished Children. Journal of Health and Allied Sciences NU. 2020 Apr; 10(01):27-30.

8. Narayana RS, Rao MJ. Chronic suppurative otitis media-aetiology and their antibiogram. Journal of Evolution of Medical and Dental Sciences. 2018 Mar 19; $7(12): 1480-4$.

9. Kalpana S, Neeta PN. Bacteriological profile and antibiogram of chronic Suppurative otitis media in a tertiary care centre, ballari-A cross sectional study.

10. Rai Y. Antibiogram of bacterial isolates causing otitis media from otitis media symptomatic persons of dharan (Doctoral dissertation).

11. Sharma C, Chand AE. Isolation and Identification of Bacteria Causing Chronic Suppurative Otitis Media and Its Antibiogram. Research \& Reviews: A Journal of Microbiology and Virology. 2019 Oct 17; 9(3):1-5.

12. Gupta R, Goel V, Sinha ON, Bisht D. Microbiological profile and changing trends of antibiogram profile in patients of chronic suppurative otitis media in a tertiary hospital in NCR region. Santosh University Journal of Health Sciences. 2018 Jul 15; 4(1):51-5.

\begin{tabular}{|c|c|c|c|}
\hline \multicolumn{4}{|c|}{ AUTHORSHIP AND CONTRIBUTION DECLARATION } \\
\hline Sr. \# & Author(s) Full Name & Contribution to the paper & Author(s) Signature \\
\hline 1 & Saeeda Nabat ul Hassan & $\begin{array}{l}\text { Topic selection and data } \\
\text { collection, Abstract and } \\
\text { recording. }\end{array}$ & Sareda \\
\hline 2 & Khushbu Farva & $\begin{array}{l}\text { Data analysis, Data collection, } \\
\text { Data analysis. }\end{array}$ & Wheretsenew \\
\hline 3 & Ghulam Asghar Bhutta & $\begin{array}{l}\text { Data analysis, Data collection, } \\
\text { Found additional literature for } \\
\text { information, Data composing. }\end{array}$ & Aseleor \\
\hline
\end{tabular}

